pÿHistorical apologies as acts of symbolic inclusion and exclusion? : Reflections on institutional apologies as politics of cultural citizenship

Löfström, Jan

2011

pÿLöfström , J 2011 , ' Historical apologies as acts of symbolic inclusion and exclusion? Reflections on institutional apologies as politics of cultural citizenship ' , Citizenship studies , vol. 15 , no. 1 , pp. 93-108 . https://doi.org/10.1080/13621025.2011.534933

http://hdl.handle.net/10138/36256

https://doi.org/10.1080/13621025.2011.534933

acceptedVersion

Downloaded from Helda, University of Helsinki institutional repository.

This is an electronic reprint of the original article.

This reprint may differ from the original in pagination and typographic detail.

Please cite the original version. 


\title{
Historical apologies as acts of symbolic inclusion - and exclusion? Reflections on institutional apologies as politics of cultural citizenship
}

\author{
Jan Löfström \\ Department of Applied Sciences of Education, University of Helsinki, Helsinki, \\ Finland \\ (Forthcoming in Citizenship Studies, do not quote without the authors's consent.)
}

\begin{abstract}
Institutional apologies for historical injustices can be conceived as acts of symbolic inclusion directed to people whose collective experiences and memories of the past have not been recognized in the hegemonic narratives of the past. However, in this article it is argued that such apologies also have exclusionary potential as vehicles of symbolic politics of citizenship in that they may designate the apologizing community so that it effectively excludes cultural 'aliens', like migrants, from the community of 'remedial' citizens. The article suggests a crucial point is the rhetoric shifts when one is appealing to both cultural and political solidarity, as when apologizing in the name of the state but simultaneously invoking 'our' nation and 'our' history. Thus the increasing number of institutional historical apologies is not necessarily incompatible with the trend of reinforcing the symbolic boundaries around 'our' historical-cultural communities that has been visible recently, for example, in the demands for cultural canons and citizenship tests in many Western societies.
\end{abstract}

\section{Introduction}

On 6 November 1942 eight Jewish refugees were deported from Finland and handed over to German authorities. Finland was at that historical moment an ally to Germany in war against the Soviet Union. ${ }^{1}$ During the war German political leaders posed their Finnish counterparts tentative questions concerning 'the Jewish question in Finland', but the Finnish Government evaded the issue with a denial that there was any 'Jewish question'. The number of native Finnish Jews was comparatively small, amounting to c. 2000 people in the 1930's. In addition c. 500 Jewish refugees from Central Europe, mostly from Germany and Austria, came to Finland after 1938. Many of them would continue to Sweden but at least 150 stayed in Finland also during the Finnish-German alliance, and one estimate suggests the number of Jewish refugees remaining in Finland in 1941-44 exceeded 350. (Illman \& Harviainen 1988, 140-141; Rautkallio 2004, 325-333, 442-453.) Despite the German authorities' occasional suggestions to have the refugees expelled they stayed in Finland throughout the war. In 1942, however, as a result of a high level Finnish Secret Police initiative eight Jewish refugees held in custody were expelled. The Government was divided on the issue but allowed the deportation. Having fallen in German hands the refugees were transported to concentration camps; only one of them would survive the war. (Rautkallio 2004.)

On 5 November 2000 a monument was unveiled in Helsinki, Finland, to honour the memory of the deported. The then Prime Minister of The Republic of Finland, Mr. Paavo Lipponen, spoke at the ceremony: 


\begin{abstract}
'Delivering the eight Jewish refugees into the hands of Nazi-Germany in 1942 was a shameful moment in Finnish history. The deed can not be undone, nor can it be explained away by using circumstances as an excuse [...] It was a decision by the Finnish Government. On behalf of the Finnish Government and all the Finnish people I apologize for it to the Jewish community [...] As the most hideous of horrendous acts the genocide of Jews and, with them, many other oppressed people has not faded in our minds. The new generation must be told about the Holocaust always when also the glorious history of the Fatherland is spoken of. ${ }^{2}$
\end{abstract}

I definitely find the Prime Minister's words sympathetic but there is an ambiguity that is interesting from the perspective of what implications the apology he made has for demarcating the limits of the community on whose behalf the apology is was made. Historical apologies by institutional actors can often be conceived as acts of symbolic inclusion, but in this paper I suggest they also have potential to symbolic exclusion: they may also designate the 'penitent community' so that it effectively excludes cultural 'aliens' from the community of 'remedial' citizens. The corollary is that symbolic historical reparations like apologies by institutional actors may serve as vehicles not only for inclusionary but exclusionary politics of cultural citizenship.

\title{
Historical apologies as acts of symbolic inclusion and recognition
}

In the last fifteen years there has been an expanding amount of literature on the issue of reparing historical injustices. The preferred terminology has varied, some authors preferring the use of 'restitution', some other the use of 'reparation', as the general term for measures of redressing past injustices. Here I use 'reparation' as the generic term that also includes symbolic redress like historical apologies by state institutions. (On the terminology see, Torpey 2006, 42-49.)

The analyses of the historical apologies trend at the turn of the Millennium have also discussed how to interpret or explain the rise of apologies. Models of explanation are many, ranging from those focusing on the replacement of future-oriented grand projects type socialism with particularistic identity projects of more limited political expectations (Torpey 2006), to those discussing the 'transformation of temporality and historicity' that is tied up with the decline of the nation-state (Olick \& Coughlin 2003), and to those that identify a new emphasis on morality in international politics after the wave of democratic transitions around the world (Barkan 2003). However one factor that almost all the analyses see as having conduced to the development is the increased political mobilization and visibility of minorities and oppressed groups wanting to have justice to their collective memories and experiences of the past.

Elazar Barkan has offered a succinct formulation when describing the negotiations on reparation (in Barkan's terminology, 'restitutions') for past injustices as a process where groups of people 'barter histories and national memories for recognition and material resources' (Barkan 2001, 345). More accurately, it is a process where the claimants demand recognition of the experiences and memories of loss and pain that are formative of their collective identity and their 'own history'. Repairing material losses can be a substantial issue but often the point of primary significance to the claimants has been recognition for the narrative of their suffering which has been marginalized in, or excluded from the hegemonic accounts of the past. Negotiating 
reparation for the past injustices is a process where the subjectivities of the victims are being (re)produced by way of (re)constructing and manifesting painful collective memories. In some cases the reparation claims may entail a demand for the recognition of the very existence of the victimized group as a distinct collective. For example, in the debates on the Armenian massacres of the 1910's and 1920's the unwillingness of the state of Turkey to consider symbolic reparation like apology has been due partly to reluctance to signal that there might be a distinct ethnic entity like the Armenians within the territory of the Turkish state. The claimants, on their part, would appreciate a symbolic reparation as a recognition of the committed injustice and, importantly, as a recognition of the Armenians as an ethnic entity. (See, Bloxham 2005, 207-233.)

The keyword here is recognition: recognition of collective experiences and memories and the historical and cultural identities based on them. As Nancy Fraser has pointed out, one of the developments in the late 20th century political discourses has been the rise of a new 'grammar of political claims-making' (Fraser 1997) whereby the focus of debates has moved further from the issues of redistribution of resources and toward the issues of recognition, the latter pertaining to questions of status parity in society's institutionalized patterns of cultural values, for example. The 'politics of recognition', as also Fraser has noted, has often tended to merge with the 'politics of identity' which hinges upon essentialising presumptions of group identities based on shared experiences (Fraser 2000). More particularly, these reconstructed shared experiences have often been experiences of oppression. For example, for certain streams of the early gay and lesbian movement the recovery of the 'untold story' of the homosexual experience of oppression in the past and a public recognition of this historical injustice was an empowering idea as the movement fought for gay and lesbian social and political rights (See, Weeks 1985, 185-201).

The significance of historical reparation like institutional apologies or memorial days lies in their capacity to serve as acts of symbolic inclusion, directed to people whose collective memories and experiences of loss have been omitted from the standard accounts of the past and, thus, whose historical and cultural identities have not been acknowledged as legitimate or relevant to society. The reparative act acknowledges the place of such memories in the narrative of the (national) past and the legitimacy of the victims' identity in the wider (national) social framework.

The potential of historical apologies to generate symbolic inclusion and reconciliation within communities has been the focus of numerous studies. For example, Melissa Nobles' study of the apology cases in Canada, New Zealand, Australia and the United States also discusses state apologies as vehicles for reshaping 'the meanings and terms of national membership', i.e. the symbolic contents and the boundaries of the national communities (Nobles 2008; see also the articles in Gibney \& al. 2008 and Barkan \& Karn 2006). There is one analytic perspective, however, missing in these studies that I find relevant. Let us look at an illustrative phrase: in his study of historical redress politics in Canada, Matt James concludes: '...redress politics appears to be forging a new discursive context in which the beneficiaries and the victims of historical injustice can begin meaningfully to discuss their joint histories and future' (James 2006, 246, italics mine). The focus is on what apologies 'do' to the victims and to the relationship between the victims and the perpetrators/beneficiaries, for example by giving new self-respect to the victims and confirming their symbolic inclusion in the 
national community. What is missing, however, is an analysis of how the apology affects the position of those who are, for all practical purposes, members of the apologizing state (her citizens) but who will identify with neither the (heirs of the) victims nor with the (heirs of the) perpetrators.

In his seminal study on the sociology of apology, Nicholas Tavuchis suggested that apologies are dyadic, involving two parties (the victim and the perpetrator), but the 'third parties' also have some importance in the process of apologizing, for example as 'judges', 'witnesses' or as audience whose reactions have relevance to the public image and credibility of the two main parties (Tavuchis 1991, 46-54). Tavuchis does not go into how the apologies redesign the symbolic boundaries of the communities of the offended and the offenders, but it is relevant also to pose the question about the community-demarcating effects of the historical apologies in regard to how they may shape the boundaries of the 'culpable' community vis-à-vis the 'third' party. As we will see, this issue can be relevant for the migrant population, for example.

At this point, it is useful to pause to consider the politics of apologies, and more generally the politics of history, as a form of politics of cultural citizenship.

\section{Politics of history as politics of cultural citizenship}

Considering that historical reparations always at some level entail a vindication of the memories and narratives that are constitutive of the victims' collective and individual identities, one can suggest that the new concern for the issues of historical reparation in the last 15-20 years intertwines closely with the rise of a notion of citizenship that emphazises the cultural dimension of citizenship, as distinct from the legal and socioeconomic ones. Already in 1997 Jan Pakulski noted that the discourses of citizenship were expanding into a field that can be characterized as issues of cultural citizenship: cultural visibility, right to dignified representation, and support to particular cultural identities and life-styles (Pakulski 1997). As for example Gerard Delanty (2002) has pointed out, it has often been unclear in the debates whether 'cultural citizenship' is defined via cultural rights and how these relate to the issue of minority rights, or how 'cultural citizenship' addresses individual cultural needs or inclusion of the excluded. However, the discourse of cultural citizenship has been a positive innovation in that it has drawn attention to the respect for people's cultural (and historical) identity as one of the prerequisites for 'full-scale' citizenship. Since symbolic representations have an important role in shaping social relations it can be argued that cultural rights are, in a sense, expanded social rights (cf. Delanty 2002, 65; Stevenson 2003, 10-18).

Historical apologies are politics of history in that they contribute to the construction of the public view of the past. They are also politics of cultural citizenship as they entail recognition of injustices that are often significant to the identity and self-perception of the victims. In this respect, they can serve inclusionary purposes; historical apologies for the previously unacknowledged suffering are to the victims a confirmation of their symbolic inclusion in the (national or other) community - their painful memories are institutionally incorporated in 'our shared memory' and 'our history'. Examples are numerous, ranging from the US apology for detaining the American-Japanese during WW II (Barkan 2001, 30-45) to the apology by President Kwasniewski, in 2001, for the persecution of Jewish Poles by their fellow countrymen during WW II (Tymowski 2002). ${ }^{3}$ 
But politics of cultural citizenship may also have an exclusionary flavour. Already in 1995, Verena Stolcke identified a trend that she called a 'new rhetorics of exclusion', a discourse that essentializes cultural differences between ethnic groups and regards them as an insurmountable obstacle to a harmonious multi-ethnic society (Stolcke 1995). 'Proper' citizenship is thereby connected to possession of particular cultural heritage. One may argue that in many Occidental societies today this view echoes, for example, in the demands for citizenship tests and educational programs where migrants are to learn the cultural 'canon' and the history of their new resident country (see, Grever 2007). Keith Banting and Will Kymlicka have been cautiously optimistic that such a 'retreat from multiculturalism' may be an overstatement since legislation on the civic and social rights of immigrants in many societies has not been altered that much even if anti-immigration rhetorics has turned more hostile (Banting \& Kymlicka 2006). Yet for example Han Entzinger (2006) suggests otherwise for the Netherlands, and also David Miller points out that the apparently 'merely' rhetorical shifts in the discourses of multiculturalism may have very real political effects (Miller 2006, 335; see also, Isin \& Turner 2007, 9-12; Joppke 2007).

For example, the exercise material for the UK citizenship test, Life in the UK Test (2007) poses practice questions on the history of immigration to the UK where the right options implicitly create a picture of the UK as a haven for the oppressed of the world (e.g. pages 9, 27, 45, 69, 81 and 87). The 'right' answers can be supported with historical evidence, however as historical interpretations they are simplifications that focus on some explanatory factor only. Considering that the alien's prospects of being granted citizenship depend on how she scores in the test, there is a close connection between her prospective legal civic status and her adhering to a particular view of history: her naturalization depends in part on knowing the 'right' interpretation of the national past. Of course, memorizing a particular account of the past when preparing for a citizenship test (or any other examination) is not to say it will be an internalized element of the person's historical consciousness, yet the message is that the 'proper' citizens endorse that account. Thus 'history' is mobilized for the purposes of designating the criteria of citizenship, and politics of history merges with politics of cultural citizenship, with a potentially exclusionary effect. (As example see also, Lomsky-Feder \& Rapoport 2008.)

This brings us to where we started the discussion, with Finnish Prime Minister at the monument for the deported Jewish refugees in Helsinki on a November day 2000.

\section{The exclusionary potential of historical apologies}

I do not doubt the good intentions in Prime Minister Lipponen's words quoted at the beginning of this text, but I want to argue that in the rhetorics he used he implicitly ended up demarcating the premises of Finnish citizenship in a way that carries a clear element of cultural exclusiveness in it - something that the speaker probably did not quite intend.

Prime Minister's words imply a moral obligation to the members of the community of 'Finnish people' to take responsibility for the actions of the political representatives of the nation in 1942 and to partake in the act of symbolic reparation, i.e. the institutional apology. The significant passage in Prime Minister's speech is, 'On behalf of [...] all 
the Finnish people I apologize'. Mr. Lipponen also refers to the Finnish Government as the agent of action in 1942 ('It was a decision of the Finnish Government') and in 2000 ('On behalf of the Finnish Government [...] I apologize'). Here the burden of the morally reprehensible past seems to be placed on the Finnish people as a political community: those exhorted to partake in the apology are people on whose behalf the Government in parliamentary democracy is entitled to speak and who, as consenting citizens, are co-responsible for the Government's action, be it in 2000 (apology) or in 1942 (deportation of the refugees). Obviously there is a presupposition here that the collective 'Finnish people' has historical continuity that makes it sensible to speak of her transgenerational responsibility and to suggest that the 'Finnish people' today bear moral responsibility also for the painful chapters of Finnish history sixty years earlier. I do not find that objectionable, but I think the problem in Prime Minister's address is his conflation of political and cultural communities.

In the final part of Prime Minister's speech we see that the symbolic amend does not speak of the moral obligations of Finnish people as a political community only; there is a line pregnant with cultural meanings, namely a reference to the 'glorious history of the Fatherland' and how it should be told also to future generations. Here, Prime Minister ends up making a rhetoric gesture that obliges first and foremost - or only? 'Finnish people' as a cultural community, i.e. a community of those who experience that they are share-holders in the ('glorious') narrative of the Finnish history where also year 1942 is 'history of the Fatherland' and a reference point of one's historical identity.

It is important to note that Finnish national identity has been characterized by a strong historical component: the history of the Finnish nation-state has been one of the major constitutive elements of national self-understanding. Particularly years 1939-44, with two successive wars against the Soviet Union and one against Nazi-Germany, were a formative collective experience that would be summoned up and recalled in numerous films and novels and, to some extent, in family tradition also decades afterwards. Still at the turn of the Millennium the story about the 'battle of national survival' was the key narrative of Finnish history among the adolescents and an important element of their historical identity (Ahonen 1998). To the Finnish people at large the history of Finland has been a source of powerful images of national community and national destiny, a 'history of the Fatherland'.

The apology by Mr. Lipponen was commented spearsely but positively in the media. For example, the leading daily paper, Helsingin Sanomat, wrote that referring to the deportation as a 'shameful moment in Finnish history' was pretty strong, considering that the Jewish citizens of Finland had lived safe also during the war and that the fate of the deported was 'only a little detail' in the tragedy of the Holocaust, however the deportation had been inhuman and cruel, hence the apology was appropriate and also the attribute 'shameful' was well motivated (Helsingin Sanomat, November 7, 2000). The paucity of media and other public reactions to Mr. Lipponen's apology in mind, it is noteworthy that three years later a journalistic documentary book, Luovutetut (The Relinquished) triggered a lively debate, arguing that Finland had been implicated in the Holocaust much more deeply; the claim was based on the author's calculations that Finland had handed over to Germans nearly 3000 prisoners of war, mostly ethnic Russian many of whom would perish in German hands (Sana 2003). The figures were not exactly a novelty but the crux of the matter was that the book explicitly called into 
question the narrative of 'the morally immaculate nation in a non-ideological war of self-defence' that had been an essential element of the national imagery (see, Tilli 2007). Apparently the apology by the Prime Minister, in 2000, did not entail as powerful a challenge to the foundational national myths, hence it did not raise that much public discussion.

I believe the intended message of Prime Minister Paavo Lipponen in his address was that the Finnish Government and the Finnish people want to take moral responsibility for the 1942 tragedy because there is a historical continuity of the state and the nation which obliges the present-day community of Finnish citizens and her political representatives. However, the final note in Prime Minister's address invokes the image of 'our shared memory' of the national past and, I would argue, it implies that the possession of such memory demarcates the moral community that is the subject of the apology, i.e. the 'Finnish people'. Hereby the door is open wide for the conclusion: if you wish to be part of the community of the Finnish people you should feel morally obliged to partake in the apology, and if you can not share this sentiment, you can not be regarded as a member of this moral and cultural community. The crux of the matter is the shift in how the Prime Minister invokes the political community of Finnish citizens and the cultural community of Finnish people as if interchangeables. This creates a problem.

\section{'Nations' and the inseparable political and cultural solidarity}

In his ceremonial apology, Prime Minister Lipponen was addressing two overlapping communities: the community of those with the sense of sharing particular memories of the national past, and the community of those who have invested Prime Minister with power to stand as their representative in parliamentary democracy. The first can be called a cultural and the latter a political community. One can distinguish the two analytically but in the lived everyday-life they may be difficult to separate.

In a world of nation-states it makes sense to regard nations as political communities, however nations are an outcome of processes of nation-building where cultural issues like historical identification and collective memories and traditions play an important role. This applies even in cases like France or the US where the rhetorics of national self-identification is strongly hinged upon an idea of shared civic principles (liberty, egalitarianism) but there is also a powerful integrating narrative of 'our nation' and her cultural traditions, embodied in particular icons, celebrations, memorials and other lieux de mémoire. Thus also in these societies the symbolic constitution of 'proper' citizenship is not unaffected by the question of one's relationship to what is conceived as part of the 'national heritage'. (See e.g. Sa'adah 2003, 91-93; Zelinsky 1988, 232245). This inescapable cultural dimension of political communities is relevant also to the discussion on institutional historical apologies.

Janna Thompson has provided a sophisticated philosophical analysis on why one can speak of transgenerational responsibility and moral obligation to historical reparation. She uses the term 'nations' in the meaning 'political agent[s] capable of making and keeping agreements'; the nations have continuity over generations, and if you wish to be part of the nation, you also have to take responsibility for her commitments in the past, i.e. commitments of those who wielded power in her name. In Thompson's view, to be a member of a nation predicates that one recognizes shared responsibility for the 
nation's past and concedes to the eventual claims of historical reparation placed at the nation's door. In fact, only nations have the kind of capacity to make agreements and exist continuously over generations which makes them liable to repare past injustices. Thompson admits though that such continuity may break, for example, when there is a radical change in the political system and people reasonably can not be considered to have consented to the politics of the former administration. (Thompson 2002, 72, 74-77.)

Thompson conceives the 'nation' only as a political community ('A nation [...] is a political society - not a cultural or religious group', p. 5). She mentions there have been 'radical doubts' on the question 'about the persistence of national identity', but she reformulates this as a 'problem of establising political identity' (p. 73). In my view Thompson here does not pay due attention to the cultural components of the 'nations' and to the implications they may have for the politics of citizenship in the context of historical apologies. ${ }^{4}$

Political communities are historically and culturally constructed with help of symbols and images; a 'pure' political community devoid of cultural content is anthropologically and sociologically not convincing. Also to Thompson the political community par excellence seems to be the nation-state, but one may argue that being a member of the nation-state is also not merely equivalent to obeying her laws, accepting the legitimacy of her political-administrative institutions, or deploying the resources of formal civic participation; it is also very much loyalty to particular (invented) traditions and sharing particular (mythical) narratives associated with the nation-state. In a phenomenology-inspired reading, Danielle Celermajer has suggested 'the nation is the political realm where ich meine Dasein habe - I have my being/place of Being', Dasein being equivalent to the 'moral/cultural/political world that is the source of individual and national identity' and where values develope and feelings like shame for the nation's past may come to propel political action such as apologies (Celermajer 2006, 166-167).

Conceiving the 'nation' as a purely political community Thompson argues that also immigrants, as citizens of their new country of residence, have a moral obligation to shoulder the nation's historical culpability also when they have not been part of the 'nation' at the time the wrong was committed (Thompson 2002, 36). This view may be well-grounded as formal philosophical reasoning on the obligations of political citizens, but anthropologically and sociologically the point of importance is that it is unlikely that the migrant at a subjective level will feel responsible for the historical moral burdens of her new resident country, and also Thompson admits this in passing (p. 36). There is a distinction between what we can call political and cultural solidarity, a distinction that Paul Ricoeur pointed out in his discussion on the phenomenology of historical apology:

'The paradox is that institutions have no moral conscience and that it is their representatives, speaking in their name, that confer on them something like a proper name and, with it, historical guilt. Certain members of the communities involved can, nevertheless, not feel personally concerned by a cultural solidarity that possesses a force different from the political solidarity from which the collective responsibility [...] results.' (Ricoeur 2004, 479.) 
Thus Ricoeur identifies the sentiment of cultural solidarity as a condition for deeper sentiments of co-responsibility for historical culpability. In Ricoeurian terminology one can say that when Janna Thompson speaks of the responsibility of the migrant to participate in historical reparation she takes into consideration only political but not cultural solidarity, and the two are not necessarily identical but potentially tensious. She fails to consider that official reparative acts by the state for historical injustices are not only a statement on the moral obligations of political citizens but a statement on how people in the community should feel about 'our past'. Historical apologies are pregnant with cultural meaning, and it is likely that the sentiment of committed moral co-responsibility will not follow from a sense of belonging in a pure political entity but rather from a sense of belonging in a collective of shared traditions and memories, as also Thompson indirectly admits (p. 73). My critique of Thompson at this point is essentially the same as the critique levelled against Jürgen Habermas for his ignoring the issue of the construction of cultural identity as a meaningful part of the issue of constituting a civil society (see, Stevenson 2003, 18-25). Political solidarity alone, as a ground for supporting historical apologies, is likely to result in apologies appearing as merely 'cheap talk' within the institutional realm of the state, and the credibility of the apology largely depends on the mobilization of sentiments in civil society where the 'passionate encounters' at issues of civic values (cf. Stevenson 2003, 24) are fuelled by competing loyalties to cultural and historical traditions, symbols and codes.

As the quote from the apology by the Finnish Prime Minister shows, the discourses of political solidarity and cultural solidarity may easily appear side by side and slide into each other as they are invoked one after the other. The demands for political solidarity are fairly unproblematic as they are basically demands to the members of the polity to accept the legitimacy of the political order and the right of the political leader to speak in the name of the community. Cultural solidarity, however, implies a sense of sharing at a deeper level of memory and tradition that is more difficult to muster and, indeed, may be inaccessible to citizens with different cultural background. Hence the demand for cultural solidarity implicit in the institutional apologies for the nation's historical burdens may effectively set the parametres of 'proper' citizenship so that it excludes cultural 'aliens' from the civic community.

The problem in the Finnish Prime Minister's speech may appear rather innocent, but the issue of exclusionary politics of cultural citizenship through politics of history is very much present and actual in the contemporary world in other similar situations of dealing with the (painful) national past, as the next chapter aims to show.

\section{Migrants, the Holocaust, and German civic identity}

Studying the historical identity of the German youth with migrant background Viola Georgi has focused, inter alia, on whether the young find points of identification in German history and what is the place of the Holocaust in their historical identity and historical consciousness. She reports an interesting incident on a visit that a group of students made to the former concentration camp of Terezin (Theresienstadt). Georgi interviewed a student of Turkish background, Bülent, on his experience of the visit. When in the crematorium of the camp, some German girls of the class had begun to weep and when Bülent had said that he did not feel like crying the girls had said to him: 'As an alien [Ausländer] you have no idea of what this is all about' which had made Bülent enraged. He told Georgi in the interview: 
II will not accept that. First [...] I was born here. Second: I have a German passport. Third: I speak the language perfectly. [...] I do not feel I were an alien here. This is my home [Heimat]. I was born here. I am living here. And I am a German, too. That is, in a way I am a German but in a way Turkish as well. I am both.' (Georgi 2000, 158-159; translation partly adopted from Loewy 2002, 13.)

The class mates' words to Bülent implied two interconnected messages: 'As you are an alien by origin you can neither understand nor share the historical burden which is a central and constitutive part of being a German today', and, 'Since you do not seem to feel more deeply about this, you are unable to understand the historical experience at the core of being a German.' The fellow students perhaps were not fully conscious of such implications of their words, but indeed their message can be interpreted (and Bülent did interpret it) like this: not being in an 'appropriately' mournful mood in his comrades' opinion Bülent was not conducting himself in a way a German would and hence he was relegated to the category of 'aliens' despite his legal status as a Germanspeaking German citizen.

At one level, the students' visit at Terezin and their reaction at the thought of the past evil and cruelties can be interpreted as a remedial gesture and a symbolic amend. The significant point for my argument here is that a particular emotional reaction (shock, tears) became invested not only with moral qualities (what is the 'appropriate' degree of grief and sorrow) but with meanings of 'proper' citizenship. Anxiety for the painful past stands out as a prerequisite for belonging in the community of 'Germans', that is, a particular kind of emotional reaction toward a particular historical injustice becomes a criterion for membership in the community that is both cultural and political, the 'Germans'. The implications for the politics of cultural citizenship are perceptively grasped by Hanno Loewy in his comment on the problem of defining membership in the German nation by feelings of transgenerational responsibility for the deeds of the Nazis:

'...such a definition of the German nation excludes all those who do not belong to the German community of fate because they can't be confronted with German 'disgrace': Jews, immigrants, refugees. The identification of a 'German fate' would, paradoxically, be the final victory of the national dream of ethnic destiny: defined by what irreversibly happened and not by common values, by descent and not by a Constitution, by blood and not by citizenship.' (Loewy 2002, 11.)

In a case where transgenerational responsibility for a particular historical injustice is a prominent part of the collective identity of a community, those with 'deficient' sense of such responsibility may become excluded from the community as cultural 'aliens'. The right to feel responsible for the historical injustice is as if reserved to the culturalhistorical collective that is 'our' penitent national community. (As an incisive study of the dilemma of the immigrant in relation to the 'German remembrance culture' see, Seidel Arpaci 2006.)

This may sound rather bleak, and I trust institutional historical apologies in the name of national communities are mostly not intended exclusionary, yet they have potential 
for serving such an outcome. The potential may be actualized when responsibility for a particular historical wrong is placed on the members of a political community (cf. Thompson's 'nations'), as usual in institutional apologies, but an individual member does not subscribe to such co-responsibility at the level of cultural solidarity that is pertinent also in the constitution of political communities. Solidarity toward the political institutions of the community and solidarity toward her traditions and historical narratives do not necessarily completely follow from each other. This dilemma is reality to migrants in particular: also as political citizens of their new country of residence, they may not always that much identify with the purportedly national cultural traditions of the country, and hence they often may not regarded as 'proper' citizens either.

This dynamics was identified, in ironic tone, also in the public reactions to President Kwasniewski's earlier mentioned apology for the persecution of Polish Jews and, in particular, for the massacre of Jews in the town of Jedwabne in 1941. The apology contained a passage rather similar to the one used by Prime Minister Lipponen in Helsinki in 2000, President Kwasniewski declaring he asked for forgiveness in the name of those "who believe that it is impossible to be proud of the greatness of Polish history without at the same time feeling pain and shame because of the wrongs Poles have committed against other people.' After the apology there was the following joke circulating that involved Emmanuel Olisadebe, an African-born soccer hero who had got Polish citizenship: " So when will Olisadebe finally become completely Polish?" "When he, too, apologizes for Jedwabne." ' (Quoted in, Tymowski 2002, 298, 301.) The joke apparently was circulated often by those with more conservative nationalist leanings as a protest against The President whose talk can be seen as an effort to convey a modern image of Poland to the international audiences (Tymowski 2002). However, the conservative nationalists could challenge the apology from the position of purportedly 'true heirs' of the national tradition, as insiders, thus the stakes in their ironic disparaging of the official redressive interpretation of the national past were not as high for them as they would have been for someone speaking from the position of a newcomer and immigrant.

\section{Situating oneself in the margins by accepting apology}

Above I have discussed historical apologies as a vehicle of politics of citizenship. The past can be mobilized for politics of citizenship in various ways, some of which bring the issue of the 'right' intrepretation of the past directly within the realm of judicial or legal implications, as for example in citizenship tests or in the so-called memory laws (lois de mémoire). I have argued that the rhetorics of shared responsibility we find in institutional historical apologies may serve to demarcate the 'penitent' community so that it excludes cultural 'aliens' from the moral community that is constructed in the exhortations to 'our' nation to recognize her historical obligations. But historical apologies may also carry implications that concern the symbolic boundaries of the collective that is being apologized to. When an institutional apology is made, people have to take a stand whether to identify themselves, culturally and historically, with the collective that is being apologized to, and that may pose a dilemma, too. The issue can be illustrated with the following examples.

As a visiting lecturer at the Dalarna Polytechnic, Sweden, in spring 2007, I had an opportunity to give a seminar on the topic 'Historical reparations and the politics of 
cultural citizenship.' At that time there was some discussion in the Swedish media on whether the state should make amends to the people of the county Scania (Skane), in South of Sweden, as an act of reparing historical injustice. Scania was part of the Danish Kingdom until Denmark lost the territory in the seventeenth century and it was annexed to the Swedish Kingdom. The subsequent policy of unification of the conquered territory by the Swedish authorities was brutal and also disastrous to the Scanian vernacular culture. As the issue was discussed in our seminar a student with Scanian family tree put forth the question if she, in the case a governmental apology for the oppression of the Scanian people and culture in the past, should regard herself primarily as a citizen of the State of Sweden ('Swedish') or as a person to whom the Swedes apologize via 'their' State ('Scanian'). The apology would set the potential recipient of apology in a dilemma on how to prioritize the competing elements of her cultural-historical identity ('Swede' - 'Scanian') and the meaningful narratives and traditions she wishes to be part of. Historical apologies implicitly demand people to (re)consider and to decide what position to take in relation to available cultural identifications. This may have political dimensions, for example in how one situates oneself in the margins or in the centre of the political landscape of the country.

That institutional apologies may have implications for the symbolic demarcation of the apologizing community and the community which is being apologized to also allows situations where the two effects so to speak operate simultaneously as in the following case which, however, is not about a state apology for any distant past. It concerns the cartoons with the figure of Prophet Mohammed that were published in the Danish newspaper, Jyllands-Posten, in 2005. The cartoons, including a picture of the Prophet with a turban in bomb-form, caused an outcry in the Moslem communities in Denmark and in other countries. The Moslem communities demanded a public apology from the newspaper for offending the sensibilities of the Moslems. Flemming Rose, editor in the Jyllands-Posten, defended the newspaper and commented on the question of apology with the following argument in an article in The Washington Post:

'We [in Denmark] have a tradition of satire when dealing with the royal family and other public figures, and that was reflected in the cartoons. The cartoonists treated Islam the same way they treat Christianity, Buddhism, Hinduism and other religions. And by treating Muslims in Denmark as equals they made a point: We are integrating you into the Danish tradition of satire because you are part of our society, not strangers. The cartoons are including, rather than excluding Muslims.' (Rose 2006.)

Rose thus contended that Jyllands-Posten had considered the Moslem community in Denmark to be 'Danish' enough to understand and to condone also this kind of more pungent joking that is, allegedly, characteristic of Danishness. The publication of the pictures should therefore be interpreted as a confirmation of Danish Moslems' status as 'proper' citizens in Danish society and, more to the point, 'proper' members of the Danish culture. An apology, to the contrary, would have implied their 'otherness' as people who have not adopted the Danish cultural norms and codes of public life and collective humour and who, therefore, are culturally alien. The argument which Rose made may have been an afterward construction, and it clearly has an assimilationist flavour, but it is not outright illogical: provided that 'Danishness' entails particular attitude to humour and to the acceptable style of political expression there is a logic 
in maintaining that no 'real' Dane would ever fancy demanding an apology for such a political cartoon. However a counterargument would be that an institutional apology here would recognize the experiences of the Danish Moslems as part of the reality of contemporary Danish society and everyday culture, thus encouraging reconsideration of the cultural contents of 'Danishness' itself. (See, Boe \& Hervik 2008.) This is, of course, what also lies at the heart of most demands for historical apologies: a request to reconsider the story of what 'we' have done and whether 'we' may have acted wrong in the past.

\section{What is at stake in the exclusionary potential of apologies?}

In this article I have discussed some, perhaps counterintuitive, implications that institutional apologies for historical injustices may have for the politics of cultural citizenship. The crux of the argument is that the apologies may have not only inclusionary outcomes (which are usually easily visible and also in the focus of the very claim for apology) but also exclusionary ones that are less direct and probably less intentional, yet not necessarily less powerful for that. My point is that in the rhetorics of these apologies there can be demands for solidarity which conflate the idea of political and cultural community so that 'our nation' as a political community becomes equivalent of 'our nation' as a historically established cultural community whereby also the notion of citizenship is given an ethnic twist: cultural belonging is made the core of citizenship. As normative statements on the proper interpretation of the past ('our past') they contribute to the construction of the symbolic and mental boundaries of historical-cultural communities, allowing access in the community to some but not others, and those boundaries have in recent years become an issue of political controverse in the Western societies as they are facing the questions of cultural integration and cohesion all the more directly. (See, Joppke 2007.)

Admittedly I have presented a limited number of examples from countries of which Finland and Poland are not traditional immigration countries, and also in Denmark and Germany extensive immigration is a more recent phenomenon than in Australia or in the UK, for example. The rhetorics of 'national values' and the conflation of the political and cultural identification in historical apologies however is not absent in these countries either, as one may see for example in a speech by Governor General Sir William Deane in Australia, in 1996:

'[A recognition of past injustices against the Aboriginals] is simply to assert our identity as a nation and the basic fact that national shame, as well as national pride, can and should exist in relation to past acts and omissions, at least when done or made in the name of the community or with the authority of government. Where there is no room for national pride or national shame about the past, there can be no national soul.' (Quoted in, Celermajer 2006, 177)

As Celermajer notes $(2006,178)$, resorting to the expression 'national soul' seems to have been an attempt to grasp the kind of 'pervasive, underlying ethos' of solidarity that modern political theory has found difficult to deal with. The ramifications of Sir William's rumination for the criteria of membership in the national community seem very demanding: being a 'proper' Australian is tied up with particular sentiments and feelings of sharing a particular historical legacy. However it would be a topic of more extensive study to look at the rhetorics of state apologies in different countries more 
closely so as to see if the rhetorics of 'ethnic nationalism' (Stevenson 2003, 44-45) and the strategy of conflating the political and the cultural is, as one might assume, a more prominent feature in the Continental European apology discourses than, say, in the Australian or Canadian discourses.

It would probably be too cynicist to conclude that the rise of institutional apologies and other forms of symbolic reparation for historical injustices in Western societies in recent decades only reflects an increased concern for demarcating and sustaining the symbolic cultural walls of 'our' historical communities at the time when those walls may appear all the more negotiable or permeable, yet the possibility of such political undercurrents in the rhetorics also in this field of politics of history should not be immediately discounted. Nowadays the laws on acquiring citizenship will not easily be set in terms that can be clearly seen as discriminatory, but more intricate forms of exclusion may be found in the cultural constitution of citizenship, for example in the expectations of tolerance to particular life-styles as a non sine qua of the citizen (cf. Joppke 2007, 44-46; Miller 2002, 234-236).

To round off the discussion, what is at stake in the exclusionary potential of official apologies if we consider it in the context of cultural citizenship? First, the conflation of the political and the cultural community that may easily take place in the rhetorics of institutional apologies, for example in the references to 'our glorious history' or 'healing our nation's soul', may effectively reinforce the notion of citizenship where particular cultural-historical identification is the prerequisite of the first-class citizen and the 'true member' of the civic community. Second, as far as historical apologies are as usual conceived of as instances of negotiation between two parties, the victims and the perpetrators, those not readily identifying with either of these two categories (the 'third') are relegated to cultural-political limbo as either inherently incapable of entering the national 'community of memory' or as obligated to assimilate in it and to abandon their particularistic collective memories (see, Seidel Arpaci 2006).

Third, in relation to the latter point in particular, historical apologies may often entail an aspect that resembles 'exclusion through liberalism' (cf. Joppke 2007; consider also the Danish cartoon affair above): repairing to a group of people that has been oppressed in the past is congruent with the principles of human rights, but the implicit obligation in a state apology for citizens to endorse the redress would place the critics of the apology in the category of illiberal antagonists to the modern human rights and thus perhaps unworthy of 'first-class' citizen's status. Elazar Barkan has suggested the trend of historical reparation can be connected to a political-moral configuration that he coins 'Neo-Enlightenment' (Barkan 2001). This term captures well the tensions inherent in the universalizing, or transcultural, presumptions in historical apologies as they make moral judgements on distant pasts, i.e. different cultures. Official apologies by state institutions enunciate a normative view on whose memory and interpretation of the past are to be endorsed, and I believe that often it can be also well justified with historical argumentation. Yet these apologies are also, as politics of history, normative statements on what should be incorporated in the shared memory and shared historical identity of the decent, responsible citizens' community that stands behind the speech act of apology.

\section{Acknowledgements}


The argument in this article was outlined in two papers, at the Conference 'Collective memory and the uses of the past,' (University of East Anglia, 8 July 2006) and at the Europan Sociological Association ESA Conference (Glasgow, 5 September 2007). I am endebted to the audience at the sessions for their comments, and in particular to Michael Cunningham for his useful remarks. I am also grateful to the referees of the Citizenship Studies for their valuable suggestions, and to Jorma Kalela, Merja-Liisa Hinkkanen, John Torpey, Jörn Rüsen and Jeffrey Olick for the encouraging response to the various versions of the papers.

\section{Notes}

1. To the Finnish leadership the alliance with Germany was a military rather than an ideological one. The Soviet Union had attempted to conquer Finland by invasion in 1939-40, and though the plan did not succeed Finland lost part of her territory in the peace treaty in March 1940. Political pressure from the Soviet on Finland continued, however. Fearing the fate of Estonia, Lithuania and Latvia which were effectively occupied by the SU during summer 1940, the Finnish Government decided to stake on Germany when Berlin offered Finland co-operation and a prospect of revanche when the anticipated war against Communism would commence. Military co-operation was designed in secrecy, and when the war between Germany and the SU broke out in June 1941, Finland joined in.

2. Prime Minister Lipponen's speech at the memorial for the eight Jewish deported, 5th November 2000 (in Finnish), $<$ www.valtioneuvosto.fi/ajankohtaista/puheet/puhe/fi.jsp?oid $=102938>$ [Accessed 22.1.2009].

3. The apology generated also negative reactions which betrayed that the retrieval of the Jewish experience of oppression by the Polish people was seen by some as an unwelcome addenda in the narrative of Poland's history.

4. Thompson concedes a 'nation is sometimes said to be a group defined by a culture, language or religion [...] but this way of using the term is not relevant to a theory of historical obligations and entitlements" as cultural groups can not "pursue policies or make and keep promises' (p. 72). Such non-political collectives may also have been 'disadvantaged by their history'; that situation may justify claims for compensation on grounds of equity, not for a reparation on grounds of historical obligation (p. 72)

\section{References}

Ahonen, S. (1998) Historiaton sukupolvi? Historian vastaanotto ja historiallisen identiteetin rakentuminen 1990-luvun nuorison keskuudessa (Helsinki: Finnish Historical Association).

Banting, K. \& Kymlicka, W. (2006) Introduction: Multiculturalism and the welfare state: Setting the context, in: K. Banting \& W. Kymlicka (Eds.) Multiculturalism and the welfare state. Recognition and redistribution in contemporary democracies (Oxford: Oxford University Press).

Barkan, E. (2001) The guilt of nations. Restitution and negotiating historical injustices (Baltimore: Johns Hopkins University Press).

Barkan, E. (2003) Restitution and amending historical injustices in international morality, in: J. Torpey (Ed.) Politics and the past. On repairing historical injustices (Lanham: Rowman \& Littlefield).

Barkan, E. \& Karn, A. (Eds.) (2006) Taking wrongs seriously. Apologies and reconciliation (Stanford: Stanford University Press). 
Bloxham, D. (2005) The great game of genocide. Imperialism, nationalism, and the destruction of the Ottoman Armenians (Oxford: Oxford University Press).

Boe, C. \& Hervik, P. (2008) Integration through insult?, in: E. Eide, R. Kunelius \& A. Phillips (Eds.) Transnational media events. The Mohammed cartoons and the imagined clash of civilizations (Gothenburg: Nordicom).

Celermajer, D. (2006) The apology in Australia: Re-covenanting the national imaginary, in: E. Barkan \& A. Karn (Eds.) Taking wrongs seriously. Apologies and reconciliation (Stanford: Stanford University Press).

Delanty, G. (2002) Two conceptions of cultural citizenship, Global Review of Ethnopolitics, 1(3), pp. 60-66.

Entzinger, H. (2006) The parallel decline of multiculturalism and the welfare state in the Netherlands, in: K. Banting \& W. Kymlicka (Eds.) Multiculturalism and the welfare state. Recognition and redistribution in contemporary democracies (Oxford: Oxford University Press).

Fraser, N. (1997) Justice interruptus: critical reflections on the 'post-socialist' condition (London: Routledge).

Fraser, N. (2000) Rethinking recognition, New Left Review (May-June), pp. 107-120. Georgi, V. (2000) Wem gehört deutsche Geschichte? Bikulturelle Jugendliche und die Geschichte des Nationalsozialismus, in: B. Fechler, G. Kössler \& T. Lieberz-Gross (Eds.) 'Erziehung nach Auschwitz' in der multikulturellen Gesellschaft (Weinheim: Juventa).

Gibney, M., Howard-Hassman, R., Coicaud, J.-M. \& Steiner, N. (Eds.) (2008) The age of apology. Facing up to the past (Philadelphia: University of Pennsylvania Press).

Grever, M. (2007) Plurality, narrative and the historical canon, in: M. Grever \& S. Stuurman (Eds.) Beyond canon. History for the twenty-first century (Basingstoke: Palgrave Macmillan).

Illman, K.-J. \& Harviainen, T. (1988) Judisk historia (Abo Akademi).

Isin, E. \& Turner, B. (2007) Transformation of citizenship: status, rights, identity, Citizenship Studies, 11(1), 37-48.

James, M. (2006) Do campaigns for historical redress erode the Canadian welfare state? in: K. Banting \& W. Kymlicka (Eds.) Multiculturalism and the welfare state. Recognition and redistribution in contemporary democracies (Oxford: Oxford University Press).

Joppke, C. (2007) Transformations of citizenship: status, rights, identity, Citizenship Studies, 11(1), pp. 37-48.

Life in the UK Test (2007). Practice questions. Second edition (London: Red Squirrel).

Loewy, H. (2002) A history of ambivalence: Post-reunification German identity and the Holocaust, Patterns of Prejudice, 36(2), pp. 3-13.

Lomsky-Feder, E. \& Rapoport, T. (2008) Cultural citizenship and performing homecoming: Russian Jewish immigrants decipher the Zionist national ethos, Citizenship Studies, 12(3), pp. 321-334.

Miller, D. (2006) Multiculturalism and the welfare state: theoretical reflections, in: K. Banting \& W. Kymlicka (Eds.) Multiculturalism and the welfare state. Recognition and redistribution in contemporary democracies (Oxford: Oxford University Press). Miller, T. (2002) Cultural citizenship, in: E. Isin \& B. Turner (Eds.) Handbook of citizenship studies (London: Sage).

Nobles, M. (2008) The politics of official apologies (Cambridge: Cambridge University Press). 
Olick, J. \& Coughlin, B. (2003) The politics of regret: Analytical frames, in: J. Torpey (Ed.) Politics and the past. On repairing historical injustices (Lanham: Rowman \& Littlefield).

Pakulski, J. (1997) Cultural citizenship, Citizenship Studies, 1(1), pp. 73-86.

Prime Minister Paavo Lipponen's speech at the memorial for the eight Jewish deported, 5th November, 2000 (in Finnish) [online]. Valtioneuvosto. Available from: http://www.valtioneuvosto.fi/ajankohtaista/puheet/puhe/fi.jsp?oid=102938 [Accessed 22.1.2009].

Rautkallio, H. (2004) Holokaustilta pelastetut (Helsinki: WSOY).

Ricoeur, P. (2004) Memory, history, forgetting. Translated by K. Blamey \& D.

Pellauer (Chicago: Chicago University Press).

Rose, F. (2006) Why I published those cartoons, Washington Post, 19 February 2006, B4.

Sa'adah, A. (2003) Contemporary France. A democratic education (Lanham:

Rowman \& Littlefield).

Sana, Elina (2003) Luovutetut - Suomen ihmisluovutukset Gestapolle (Helsinki:

WSOY).

Seidel Arpaci, A. (2006) National memory's Schlüsselkinder: migration, pedagogy, and German remembrance culture, in: S. Taberner \& P. Cooke (Eds.) German culture, politics, and literature into the twenty-first century: Beyond normalization (Rochester NY: Camden House).

Stevenson, N. (2003) Cultural citizenship, cosmopolitan questions (Maidenhead: Open University Press).

Stolcke, V. (1995) Talking culture: New boundaries, new rhetorics of exclusion in Europe, Current Anthropology, 36(1), pp. 1-13.

Tavuchis, N. (1991) Mea culpa. A sociology of apology and reconciliation (Stanford: Stanford University Press).

Thompson, J. (2002) Taking responsibility for the past. Reparations and historical justice (Cambridge: Polity Press).

Tilli, J. (2007) Elina Sanan Luovutetut jatkosotaan liittyvän historiapolicyn

kritiikkinä, in: T. Haapala \& H.-M. Kivistö (Eds.) Vai pelkkää retoriikkaa? (Jyväskylä: University of Jyväskylä).

Torpey, J. (2006) Making whole what has been smashed. On reparations politics (Cambridge MA: Harvard University Press).

Tymowski, A. (2002) Apologies for Jedwabne and modernity, East European Politics and Societies, 16(1), pp. 291-206.

Weeks, J. (1985) Sexuality and its discontents. Meanings, myths and modern sexualities (London: Routledge \& Kegan Paul).

Zelinsky, W. (1988) Nation into state. The shifting symbolic foundations of American nationalism (Chapel Hill: University of North Carolina Press). 